Pakistan Journal of Geology (PJG)

Journal Homepage: http://www.razipublishing.com/journals/pakistanjournal-of-geology-pjg/

\title{
SEDIMENTARY FACIES ANALYSIS OF NAGRI FORMATION, KASHMIR BASIN, SUB- HIMALAYAS, PAKISTAN
}

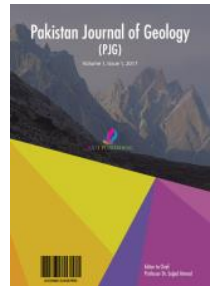

Noman Abbasi*, Muhammad Sabir Khan, Muhammad Saleem Mughal, Muhammad Yasin

Institute of Geology, University of Azad Jammu and Kashmir, Muzaffarabad, 13100, Pakistan.

*Corresponding Author email: nomanabbasi51@gmail.com

This is an open access article distributed under the Creative Commons Attribution License, which permits unrestricted use, distribution, and reproduction in any medium, provided the original work is properly cited

\section{ARTICLE DETAILS}

Article history:

Received 12 May 2017

Accepted 12 July 2017

Available online 17 October 2017

Keywords:

orogeny, para-conglomerate, orthoconglomerate, overbank, braided

\section{ABSTRACT}

Nagri Formation, the subject of this study, lies in northeastern part of Kashmir basin, Pakistan along a belt of about 250-kilometer square. The Nagri Formation forms alternate beds of sandstone, claystone and/or mudstone. These are molasse deposits formed during the Himalayan orogeny and are early Pliocene in age. The Formation consists of six sedimentary facies: para-conglomerate (N1) comprised of massive conglomerates with the absence of grading and matrix supported fabric of clayey sand; ortho-conglomerate (N2) are normal graded conglomerates and are poorly sorted having clasts supported fine to very coarse grain matrix; massive sandstone (N3) is composed of medium to coarse sized grains, contains massive sandstone beds and is poorly sorted with scattered pebbles at some locations; cross bedded sandstone (N4) consist of to medium to coarse textured, cross bedded sandstone; parallel laminated sandstone (N5) comprising fine to coarse grained and poorly sorted sandstone beds with thin parallel laminations; and mudstone (N6) comprised of massive claystone's, siltstones and mudstone that lack any noticeable sedimentary structure. The conglomerates, sandstone and mudstone/siltstone/claystone facies are stacked in ascending order and are deduced as a sequence of channel bar and floodplain or over bank deposits confined to a braided fluvial system.

\section{INTRODUCTION}

The Nagri Formation has paced out a 55-km length and $30 \mathrm{~km}$ width in Northeastern part of Kashmir basin, Pakistan along a belt with preferred orientation of deposits towards northeast and southwest directions. The information regarding the environment(s) of deposition of Nagri Formation is ambiguous and no significant work has been done from this perspective in the study area (Figure 1; Figure 2). However, assiduously interpreted thick Nagri Formation sandstone as the sinuous and braided stream deposits in the Indus basin (Potwar sub-basin) Pakistan [1]. The stacking patterns of facies have been acclimatized by the movements of streams within single or multiple fluvial belts. Furthermore, the thickness of few to tens of meters has also been paced out by a scientist for the inclined strata/ storeys [1]. In addition, mudstone and thin sandstone bodies of Nagri Formation are declared as the overbank deposits [1]. On the other hand, one of researcher has revealed that the sand and dislodged gravels are transported and deposited by means of ancient braided stream patterns [2].

The fundamental requisite of the research also includes sedimentary facies interpretation on a regional scale.

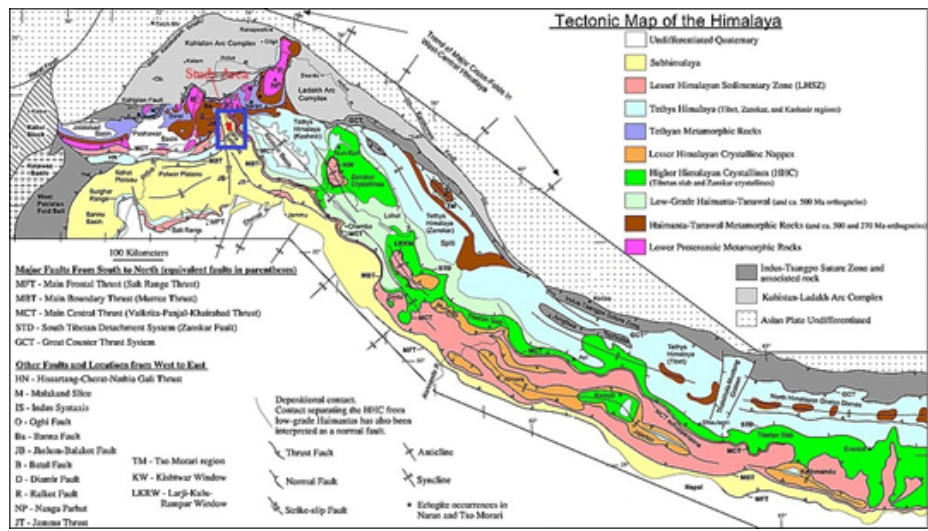

Figure 1: Geological map showing the study area modified after [3].

\section{GEOLOGICAL SETTING}

The Sub-Himalayas are comprised of a narrow belt of folded Neogene mollasse sediments of Rawalpindi Group and Siwaliks [4]. The Himalayan foreland basin is surrounded by Main Boundary Thrust (MBT) and Himalayan Frontal Thrust towards its northern and southern halves, respectively. The Himalayan foreland basin has engulfed sedimentary mollasse sequences in the area. Stratigraphically, the Neogene mollasse deposits include the rocks of Rawalpindi group containing Murree Formation, Kamlial Formation and Siwaliks group including Chinji Formation at the base, Nagri and Dhok Pathan Formations in the middle and Soan Formation at the top. The mollasse deposits are bounded by Hazara Kashmir Syntaxis on the northwestern and northeastern sides in Kashmir basin and the nearby areas. A scientist coined the term 'Northwest Himalayan Syntaxis' for the broad Geological structure of the Himalayas that make an abrupt hairpin bend in the Hazara and Kashmir region [5] The subject of this study confined Nagri Formation of the mollasse sequence of the area.

\section{METHODOLOGY}

The Geology of the mountains was studied in milder climes for 90 days field work. The toposheet no. 43-F/12, Survey of Pakistan was used in surveys The lofty tops of mountains were difficult to surmount, so the sedimentological aspects were studied along the roadside and drainage. The Brunton compass served as the key appliance in the measurement of the attitude of rock formations. Furthermore, the tape-compass-clinometer method was preferred in section measurement. The rock samples collected from the field were further analyzed in the Laboratory. The structural features were snapped in the field by a camera.

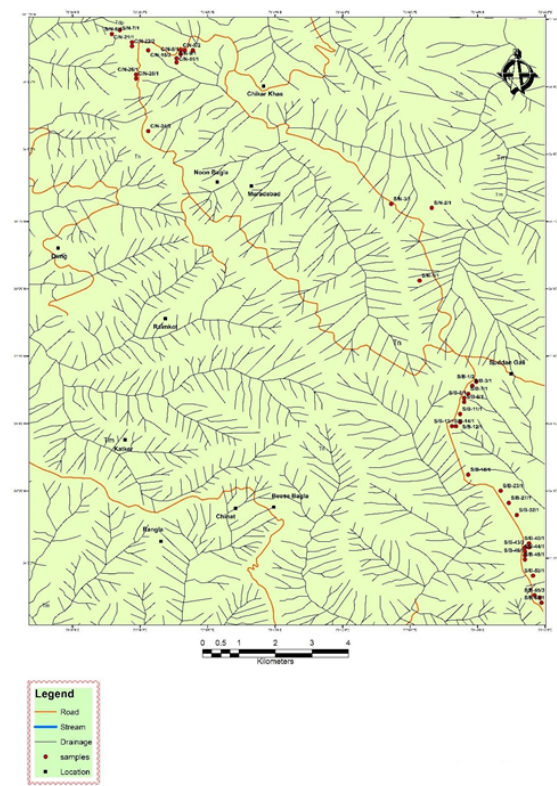


Figure 2: Sample location map of study area. The location of samples is helpful in tracing the actual paths followed during field surveys.

\section{RESULTS}

\subsection{Sedimentary Facies}

The sandstone of Nagri Formation with alternate beds of conglomerates and siltstone/ claystone/mudstone formed a region, $55 \mathrm{~km}$ in length and $30 \mathrm{~km}$ in width in the Sub-Himalayas, Kashmir basin, Pakistan. So, the Nagri rock Formation forms the conglomerate (Para \& orthoconglomerates), sand (Massive, Cross bedded, \& Parallel laminated sandstone) and clay (Claystone/Siltstone/Mudstone) dominated facies. The Mudstone Facies are however rare.

\subsection{Conglomerate - dominated facies}

\subsubsection{N1: Para-conglomerate facies}

This Facies are matrix supported (clays) and massive channel conglomerates (Figure 3) ranging in thickness from 1.5 meter to 20.3 meters. The conglomerates are composed of pebbles, cobbles, and gravels size clasts of $1.5 \mathrm{~cm}$ to $15 \mathrm{~cm}$ diameter. These clasts are subrounded to rounded representing long history of transportation and are composed of quartzite, volcanics, dolomite, limestone and sandstone.

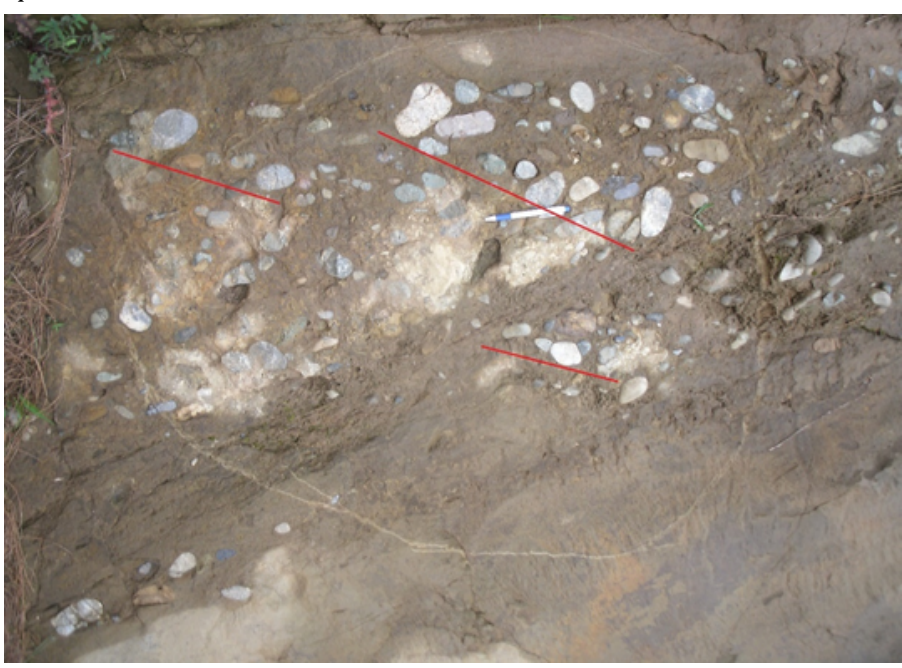

Figure 3: Paraconglomerates.

These clasts show pebble imbrication, moderate to well sorted and systematically arranged in the direction of long axes. This type of facies is light grey in colour. The petrified wood is completely absent in paraconglomerate facies. The lower contact of this lithofacies is eroded, rough and scoured which is the character of flowing channel. These facies make about $4 \%$ of the Nagri Formation.

\subsubsection{N2: Ortho-conglomerate facies}

The clasts supported ortho-conglomerates (N2) dominant over the Para conglomerate lithofacies in the conglomerates (Figure 4). These facies comprised of conglomerate beds range in a thickness of 0.4 meter to 13.7 meters graded normally into sandstone.

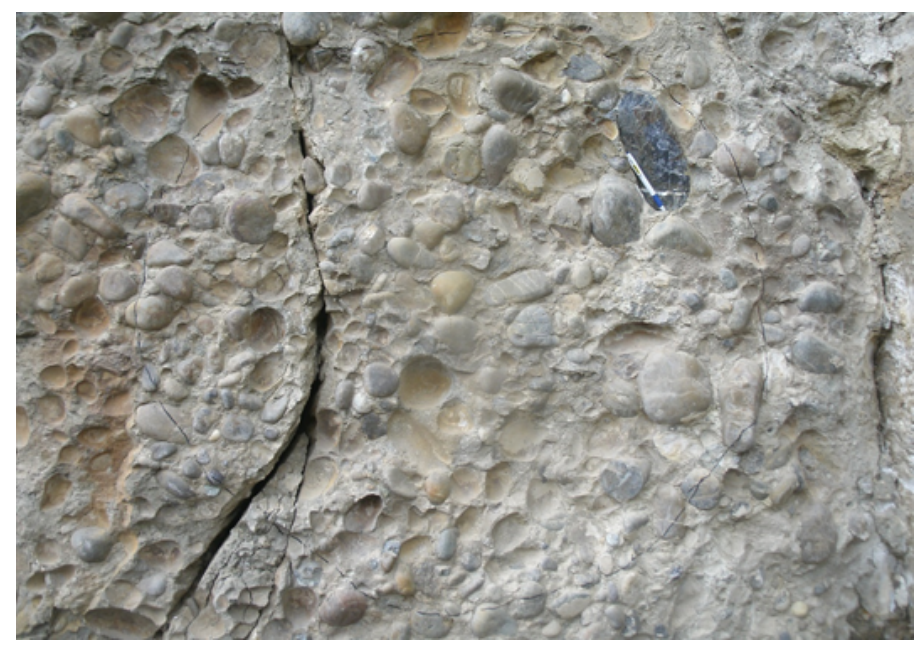

Figure 4: Orthoconglomerates
The facies formed gravels and cobbles sized particles of channel lag deposition at base to pebbles and then finally graded normally into sandstone (Figure 5). The conglomerates particles generally range in size from $1 \mathrm{~cm}$ to $11.2 \mathrm{~cm}$ in diameter. The clasts are subrounded to rounded, and consist of quartzite, volcanics, dolomite, limestone and sandstone. The sandstone is massive, coarse to medium grained and horizontally stratified. The sandstone beds commonly range from $20 \mathrm{~m}$ to $70 \mathrm{~m}$ in thickness. This type of facies is poorly sorted and highly disorganized. The clasts are highly scattered with no pebble imbrication direction. The matrix forms sand (both fine and coarse) and clasts. This type of conglomeratic bed is also light grey in colour. The petrified wood is also completely absent in these facies. The lower contact of this lithofacies is also irregular and erosional. It forms about $7 \%$ of the Nagri Formation.

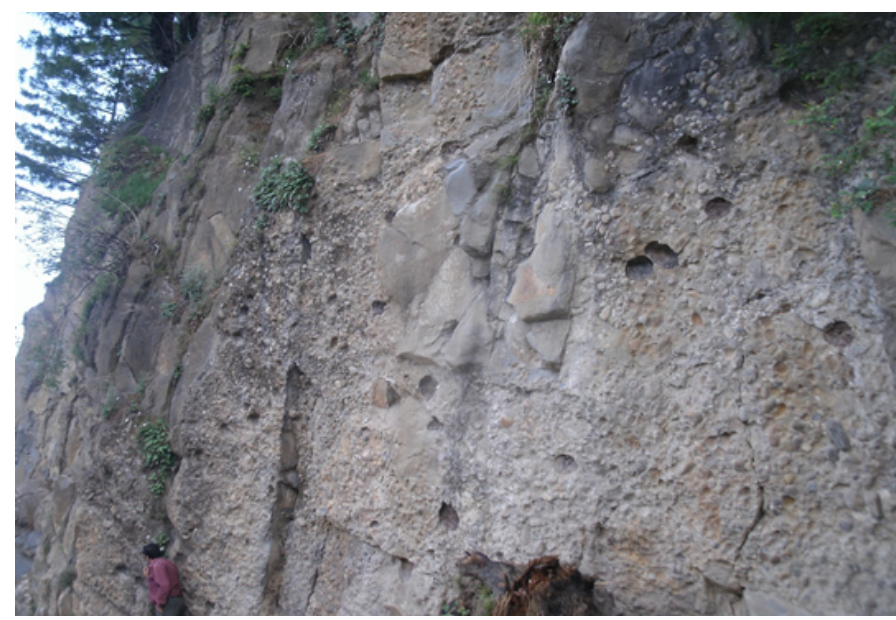

Figure 5: Orth conglomerate graded into sandstone.

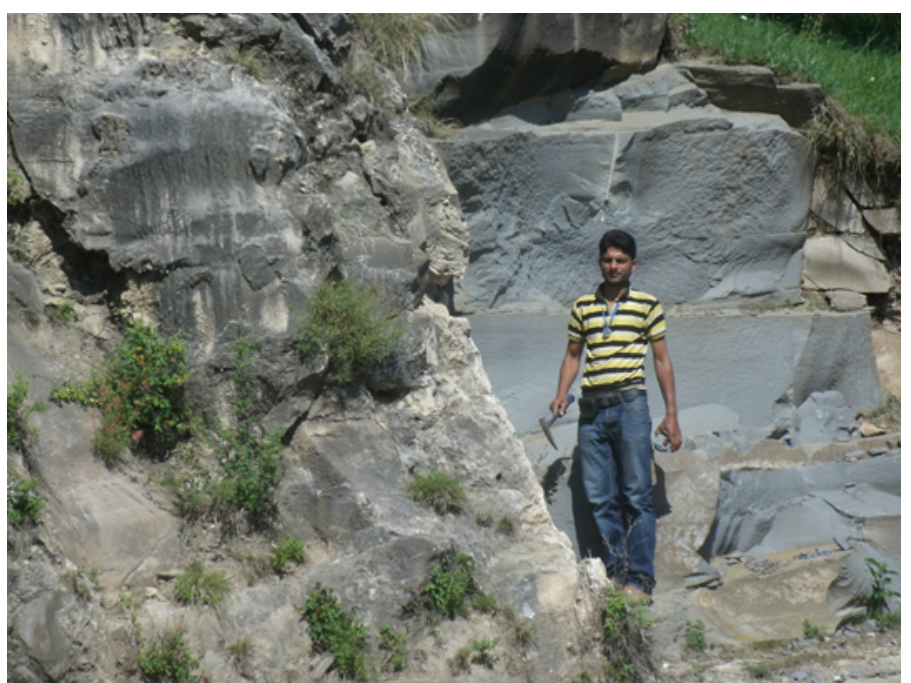

Figure 6: Massive sandstone facies

\subsection{Sandstone-dominated facies}

\subsubsection{N3: Massive sandstone facies}

The facies are comprised of massive beds and medium to coarse textured sandstone (Figure 6). The sandstone beds range in a thickness of few meters to about 40 meters. The sand grains analyses under the microscope are angular to subrounded. The sandstone is poorly sorted and immature. The scattered pebbles are present at some locations ranging from $2 \mathrm{~cm}$ to $5 \mathrm{~cm}$ in diameter. The petrified wood fossils are commonly observed in this lithofacies. These facies are poorly consolidated and does not consist of any significant sedimentary structure. The facies are ash grey and reddish brown (due to iron leaching) in colour. The facies have sharp base and forms about $48 \%$ of the Nagri Formation.

\subsubsection{N4: Cross bedded sandstone facies}

This type of lithofacies contained small proportion of the Nagri Formation as a whole. The sandstone is coarse to coarse grained and composed of planar and trough cross bedding. The cross bedded facies (Figure 7) falls at the thickness of few centimeters to several of meters and the thickness of an individual set generally lies between 25 to 100 centimeters. This sandstone facies also contain clasts at some places of commonly pebble size ranges upto $5 \mathrm{~cm}$ in diameter. The sand grains have 
angular to rounded outlines, unconsolidated and poorly sorted with floating fabrics. The petrified wood fossils are absent. The facies are ash grey to light ash grey in colour. The facies possess sharp bases and forms atleast $5 \%$ of the Nagri Formation.

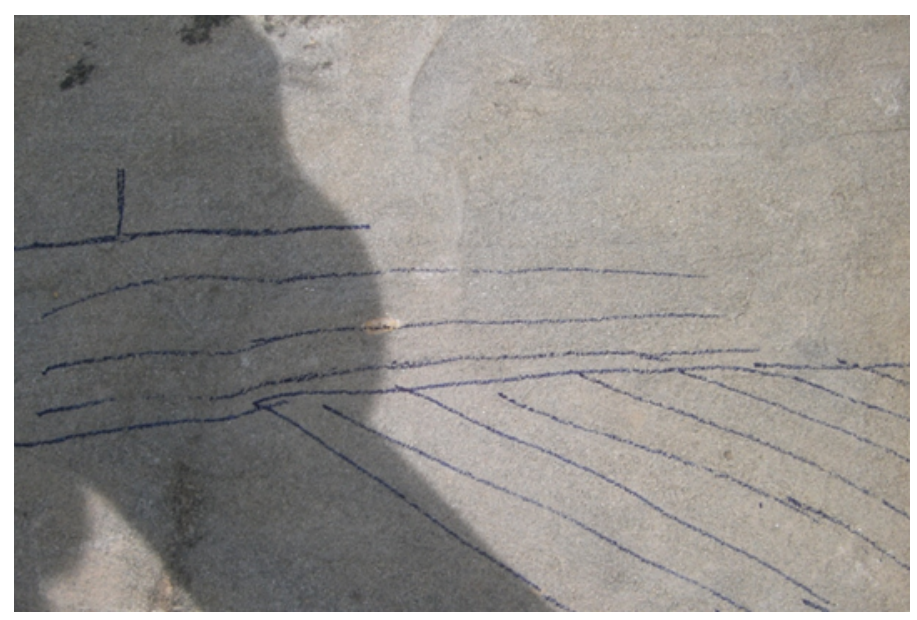

Figure 7: Cross bedded sandstone facies.

\subsubsection{N5: Parallel laminated sandstone facies}

The lithofacies are categorized by parallel laminations (Figure 8) in sandstone. The sandstone is horizontally stratified and comprised of fine to medium grained, very thin laminae and generally contains sub angular to rounded grains. The sandstone exhibits floated grain fabric, friable and is poorly sorted. There is complete absence of wood fossils and the facies is light grey in colour. The facies are characterized by sharp base and make atleast $6 \%$ of the Nagri Formation. Moreover, it also occurs as interbeds.

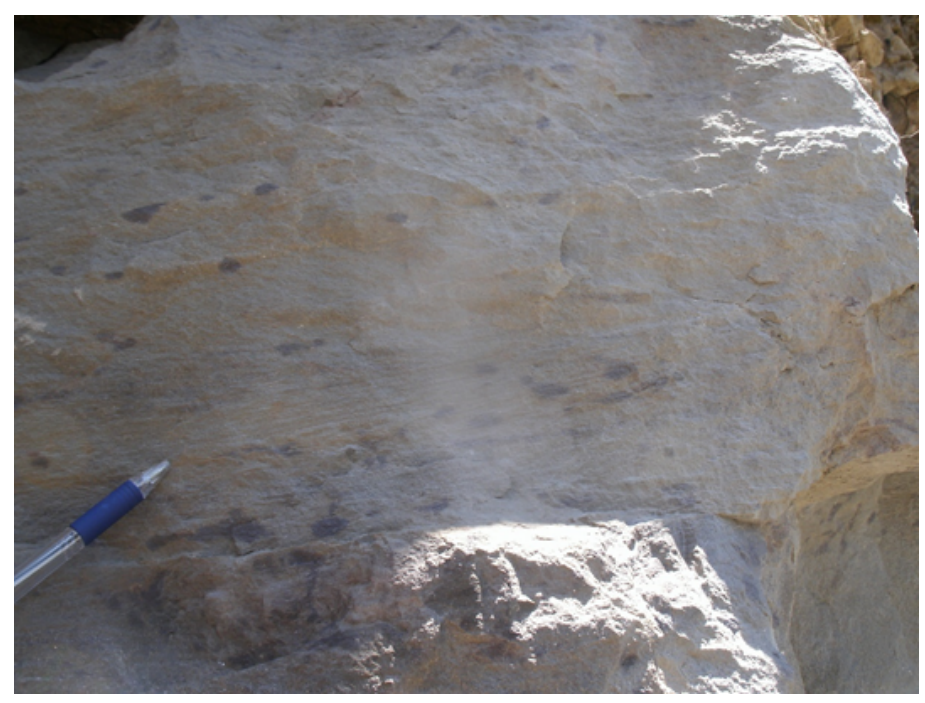

Figure 8: Parallel laminated sandstone facies.

\subsection{Claystone - dominated facies}

\subsubsection{N6: Claystone/Siltstone/Mudstone facies}

This is the second most dominant facie in Nagri Formation. It contains massive claystone/siltstone/mudstone (Figure 9) and devoid of noticeable sedimentary structures. However, the mudstone is bioturbated at some locations. These fine-grained facies have red, brown and variegated colors. The organic fragments especially plant leafs are present at some locations. The base of the facies is abrupt and rough but without erosion and is about $30 \%$ of the Nagri Formation.

\subsection{Interpretation of Depositional Processes/Discussion}

The para-conglomerates are poorly sorted and grading is absent. They lack stratification and wood fossils. Their coarseness and the lack of stratification are few parameters suggesting debris flow origin for these facies [6-14]. The restriction of the relative movements among clasts can be revealed through the absence of preferred fabric and the flows occupied pre-existing channels passively [15].

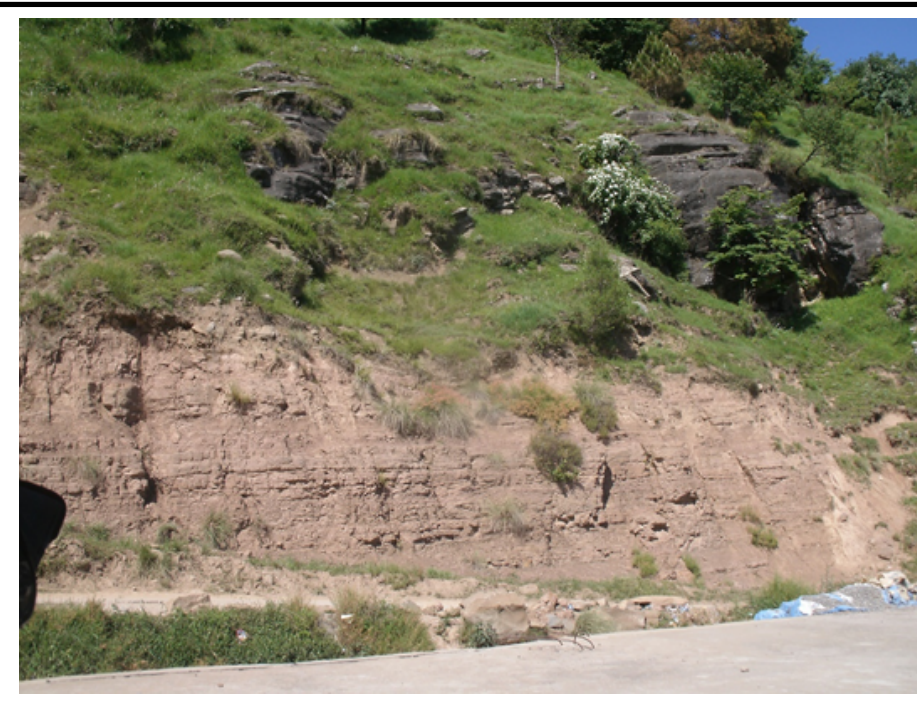

Figure 9: Mudstone/Claystone facies

The extent of thickness exhibited by ortho-conglomerate (N2) facies beds is an indication of the mass flows or streams having significant magnitude. The framework's support spotted in the conglomerates may possibly be the result of progression and deposition of clasts along a bed. The sand matrix (coarse grained) are presumed to have been carried through in suspension concurrently with the rolling of big sized clasts in bedload. A limited rolling of clasts bedload symmetrical to ambient flow conditions signals, the fundamentally unstratified character of the conglomerates and also a lack of pebbles imbrications.

The normal grading of the facies N2 is a sign of deposition of a single current with the reduction in strength of flow and energy of the channel. The base of the facies marked with erosion shows channel scour which might have been created by avulsion at comparatively high flood stage [16-18]. It can also be inferred that the deposition of facies N2 took place subsequent to a flood which caused erosion of strata facie's base. The conglomerate sandstone facies symbolize stream floor deposits, typified by largely scattered clasts with no imbrication. This kind of sandstone are also regarded a product of gravel dominated, high energy channel flow [19].

The gravelly very coarse sand of Orth conglomerate (facies N2) was carried in suspension by the similar flow dislodging the underlying conglomerate as bed load [12].

The sand wedges show that the floundering flow velocities have deposited conglomerate sandstone couplet towards the end of discharge cycle. The confrontation of the Orth conglomerate and overlying sandstone wedge indicates changes from bedload rolling to suspension during the main transport mechanism. The gravelly facies also indicate their deposition in stream. Facies $\mathrm{N} 2$ is overlain by sandy and fine Facies.

The alluvial fans may accumulate local sediments of angular to sub-angular fragments due to rapid and short history of transportation. This transportation is confined to a narrow stream or channel where it emerges onto a broad alluvial plain or trunk river and all indicate that the conglomerates are not fluvial fan products [20]. The study of conglomerates of the area suggests absence of any localized structural feature. These are poorly sorted, exhibited lack of pebble imbrication and are lenticular. These all parameters nullify the beach origin of these conglomerate. The meandering streams largely deposited the sands, silts and clays size particles [21]. Therefore, the larger clasts upto gravel size conglomerate particles are surely not associated to meandering river systems. Furthermore, lack of striations indicates non- glacial origin for the conglomerates. The pure Bouma sequence is also absent suggest that the conglomerates are not turbidity current deposits. The sedimentation record in a particular channel or composite channels revealed aggradation beyond the adjacent area. The competency of stream is progressively reduced in response to the declination of the slope. These processes have been revealed in overall normal grading or fining upward sequence. Possibly during flood episodes, the channel barriers are breached and diverted streams into the lesser topographic regions. The ancient channels or channel structures are abandoned and the fine-grained sediments are youngest $[18,22]$.

The sandstone of massive bedded facies N3 might have been formed in reaction to quick deposition or due to post depositional deformations [23-25]. In the aforementioned analysis, deformation is reflected as irrelevant, established on the lack of characteristic features in any bed 
accompanying facies N3. Consequently, these facies are understood as subsequent from transportation and deposited by short term existed, floods streams.

The occurrence of planar bedding in the $\mathrm{N} 4$ facies, the deviations in grain size and the thick sets of cross beds advocate their deposition by lateral migrating dunes (2-D) or channel bars. The lee faces of cross beds were the probable locations exhibiting the avalanches of sands and granules. The textural variations (the granules and coarse sand particles) are concentrated in the foresees because the sand is normally sorted by the development of current migration upto the stoss side of the dunes [15]. High horizontal and vertical connection of the cross bedded sandstone was possibly owed to low subsidence rates, resulting in less preservation of overbank finer sediments $[25,26]$.

The parallel stratification in the facies N5 is the product of upper flow during normal bed conditions. The plane stratification with thin parallel lamellae might indicate low rate of sedimentation. Bearing in mind the nature of facies N3, N4 and N5 and their close relation with lithofacies N2 and $\mathrm{N} 6$, these sandstone lithofacies are considered as channel and point bar deposits. The sandstone overlies by claystone, siltstone and mudstone facies.

The claystone, siltstone and mudstone lithofacies and their massive nature might be formed due to a very homogeneous and perhaps rapid deposition from suspension and because of absence of platy grains [27]. The red colour indicates floodplain deposits of claystone, siltstone and mudstone in a well-drained and oxygenated environment [29]. This facies (N6) represents floodplain deposits. Based on all these interpretations, it is obviously directed that the gross fining upward relationship characterizes a channel bar to overbank or floodplain depositional sequence in a braided fluvial system. Furthermore, the rounded to sub rounded and lenticular shape of pebbles, cobbles and gravels also favours fluviatile origin of conglomerate deposits. The conglomerates appearing in a linear array are definitely deposited in a valley confined to braided river channels.

\section{CONCLUSION}

This article concludes that the Nagri Formation in Northeastern part of Kashmir basin, Pakistan is deposited in a braided fluvial system. The study agrees with the findings of earlier studies by some author conducted on the Indus basin (Potwar sub-basin and Kohat sub-basin respectively) of Pakistan.

\section{REFERENCES}

[1] Khan, I. A., Bridge, J. S., Kappelman, J., and Wilson, R. 1997. Evolution of Miocene fluvial environments, eastern Potwar plateau, northern Pakistan. Sediment, 44, 221-251.

[2] Azizullah, Khan, M. A. 1998. Lithostratigraphy and depositional system of Siwaliks of Singhar-Surghar Range, Thakhti Nasrati-Shanawah area, district Karak, Pakistan. In: Ghaznavi, M. I Raza, S. M. and Hasan, M. T. (eds.), Siwaliks of South Asia. Geological Survey of Pakistan, 71-80.

[3] Lombardo, B., Rolfo, F., and Compagnoni, R. 2000. Glaucophane and barroisite eclogites from the upper Kaghan nappe: Implications for the metamorphic history of NW Himalaya, in tectonics of the Nanga Parbat Syntaxis and the Western Himalaya. Geological Society, London, Special Publications, 170, 411-430.

[4] Greco, A. 1991. Stratigraphy, Metamorphism and Tectonics of the Hazara Kashmir Syntaxis Area. Kashmir Journal of Geology, 8 (9), 39-65.

[5] Wadia, D. N. 1931. The syntaxes of North-west Himalayas: its rocks, tectonics and orogeny. Record Geological Survey of India, Memoirs, 63 (1), 129-138.
[6] Blissenbach, E. 1954. Geology of Alluvial fans in Semi-Arid Regions. Geological Society of America Bulletin. 65, 155-190.

[7] Lowe, D. R. 1976. Gain flow and Grain Flow Deposits. Journal of Sedimentary Petrology, 46, 188-199.

[8] Hooke, R. 1967. Processes on Arid Region Alluvial Fans. In: Depositional Sedimentary Environments (eds. H. E. Reineck and I. B. Singh). Berlin Heidelberg, New York, 1975, 255-256.

[9] Beaty, C. B. 1963. Origin of Alluvial Fans, White Mountains, California and Nevada. Annals of the Association of American Geographers, 53, 516-535.

[10] Fisher, R. V. 1971. Features of coarse grained high concentration fluid and their deposits. Journal of Sedimentary Petrology, 41, 916-927.

[11] Johnson, A. M. 1970. Physical Processes in Geology. Freeman, San Francisco, California, 575.

[12] Walker, R. G. 1975. Generalized facies models for resedimented conglomerates of turbidite association. Geological Society of America, Bulletin, 86, 737 - 748 .

[13] Bull, W. B. 1972. Recognition of Alluvial Fan Deposits in the Stratigraphic Record. In: Recognition of Ancient Sedimentary Environments (ed. By J. K. Rigby and W. K. Hamblin). Special Publication Society Economic Paleontologists and Mineralogists Tulsa, 16, 63-68.

[14] Kim, B. C., and Lowe, D. R. 2004. Depositional processes of the gravelly debris flow deposits, South Dolomite Alluvial fan, Owens Valley, California. Geosciences Journal, 8 (2), 153-170.

[15] Miall, A. D. 1996. The Geology of Fluvial Deposits: Sedimentary Facies, Basin Analysis and Petroleum Geology. Berlin: Springer Verlag.

[16] Williams, P. F., and Rust, B. R. 1969. The sedimentology of braided river. Journal of Sedimentary Petrology, 39, 649-679.

[17] Yagishita, K. 1997. Paleocurrent and fabric analysis of fluvial conglomerate of the Palaeogene Noda Group, northeast Japan. Sedimentary Geology, 109, 53-71.

[18] Miall, A. D. 1977. A review of the braided river depositional environment. Earth Science Review, 13, 1-62.

[19] Rust, B. R., Koster, E.H. 1984. Coarse alluvial deposits. In: Walker, R. G. (Ed.), Facies Models. Geol. Assoc. Canada 53-69.

[20] Rust, B. R. 1979. Facies Model 2. Coarse Alluvial Deposits. In: Facies Model (Edited by R. G. Walker). 5th Reprint. Geoscience Canada, Ontario, 9-12.

[21] Nichols, G. 1998. Sedimentology and Stratigraphy. Blackwell Science Ltd. $\mathrm{p} 354$.

[22] Dyer, K. R. 1970. Grain Size Parameters for Sandy Gravels. Journal of Sedimentary Petrology, 40 (7), 616-620.

[23] McCabe, P. J. 1977. Deep distributary channels and giant bedforms in the Upper Carboniferous of the Central Pennines, northern England. Sedimentology, 24, 271-290.

[24] Johns, B. G., and Rust, B. R. 1983. Massive sandstone Facies in the Hawkesbury Sandstone, a Triassic fluvial deposit near Sydney, Australia 